\title{
IMPACTS OF MACROECONOMIC POLICIES ON OUTPUT IN THE CZECH REPUBLIC: AN APPLICATION OF ROMER'S IS- MP-IA MODEL
}

\author{
Yu HSING*
}

\begin{abstract}
:
Extending Romer's IS-MP-IA model to include foreign trade and exchange rates and applying the GARCH method, the study came to the conclusion that real gross domestic product is negatively associated with the inflation rate, exchange rate depreciation, and the foreign interest rate and positively affected by government deficit spending and world output. Therefore, inflation targeting is an appropriate monetary policy, and the depreciation of the koruna would be harmful to the Czech economy even though it would help the export sector.
\end{abstract}

Keywords: IS-MP-IA model, inflation targeting, exchange rates, deficit spending, GARCH

JEL Classification: E5, E6, F4

\section{Introduction}

In recent years, like many other countries, the Czech Republic experienced economic fluctuations. Real gross domestic product (GDP) at the 1995 prices reached CZK 1,440.35 billion in 1996, declined to 1,429.33 billion in 1997 and 1,414.42 billion in 1998, and then gradually rose to 1,542.22 billion in 2002. Based on the first three quarters, it was estimated that real GDP in 2003 would be greater than the value in 2002 . On the macroeconomic level, several major factors may be related to these economic fluctuations. Due to the change in the exchange rate regime, the value of the koruna against the USD declined by $26.7 \%$, from $27.33 \%$ in 1996 to $34.64 \%$ in 1997. Exports went up because Czech-made products were cheaper and more competitive. However, the value of imports also rose because it cost more to buy foreign products. To defend the koruna and contain potential inflation, the central bank raised the bank rate from $12.4 \%$ in 1996 to $14.75 \%$ in 1997 and gradually lowered it to $2.00 \%$ in 2003. Lending rates went up from $12.54 \%$ to $13.20 \%$ during the same period and gradually declined to $5.31 \%$ in 2003 . Relatively high interest rates discouraged households and businesses to borrow and spend. Due to currency depreciation and higher import costs, the inflation rate rose to $10.6 \%$ in 1998 and gradually declined to $0.1 \%$ in 2003 . To stimulate the economy, the govern-

*) College of Business and Technology, Southeastern Louisiana University, Hammond, LA 70402, USA (e-mail: yhsing@ selu.edu). 
ment employed expansionary fiscal policy by increasing deficit spending from 1.8 billion in 1996 to 15.9 billion in 1997 and 45.57 billion in 2002 . Dufek and Vávra (2002) and Janáček and Zamrazilová (2003) detailed the progress of record-low inflation and the Czech economic growth in recent years.

This paper attempts to examine the determinants of real output in the Czech Republic and differs from most of previous studies in several aspects. First, I applied Romer's (2000) IS-MP-IA model which focuses on the inflation-output relationship and the federal funds rate as a monetary policy instrument. Romer's model is suitable to the Czech Republic because the Czech National Bank (CNB) uses key interest rates such as the two-week repo-rate as the main monetary policy instrument and has worked toward inflation targeting since January 1998. Second, this study extends Romer's model by adding the trade sector in the IS function and the exchange rate and the foreign interest rate in the MP function. It is possible that the CNB would respond to currency depreciation or an increase in the foreign interest rate by raising the domestic interest rate in order to maintain the stability of the currency and keep the domestic interest rate level in line with the world interest rate. Third, this paper applies the GARCH (see Engle, 2001) model to estimate parameters so that regression errors may be a function of past squared errors and past error variances.

\section{Literature Survey}

Several recent articles examined monetary policy, inflation targeting, exchange rates, and other related issues. Clarida, Gali and Gertler (1998) maintained that in pursuing monetary policy, targeting the inflation rate would be better than targeting the exchange rate. Brada and Kutan (1999) studied the reasons for the decline in inflation in three transition countries including the Czech Republic. They showed that the decline in inflation was largely attributable to decreased import prices and that monetary policy in these countries was not backed up by fiscal policy and was hindered by multiple goals. Jonáš and Mishkin (2003) analyzed inflation targeting for three transition countries including the Czech Republic. They found that the pursuit of inflation targeting has helped reduce inflation and their economies and suggested that the central bank should not actively manipulate with the exchange rate, should communicate more with the government and the public, and should avoid the over-shooting or under-shooting of the inflation target.

Based on pooled data including the Czech Republic, Halpern and Wyplosz (1995) found that the exchange rate was overvalued and moved toward the equilibrium level. Begg (1998) examined the impacts of abandoning the exchange rate pegging in May 1997. He indicated that the koruna depreciation may be affected by the Asian financial crisis and that the koruna went back to its normal level after some adjustments. However, the government sterilization program delayed the adjustments in fiscal policy. Kutan and Brada (1998) analyzed the koruna crisis in May 1997 and subsequent stagflation with declining output, rising unemployment, and increasing inflation. They argued that the key problem of the macroeconomic situation was the relatively high inflation rate compared with most of neighbouring countries.

In reviewing the exchange rate crisis in May 1997, Šmídková (1999) has several interesting findings. The competitiveness indicator showed that the koruna was overvalued, financial indicators sent some warning signals, and debt and insolvency indicators did not suggest any external crisis. The fundamental equilibrium exchange rate model indicated that the koruna was overvalued in 1996 and that a policy change was needed. Durčáková and Mandel (2002) discussed the selection of an appropriate exchange rate regime and the influence of exchange rates on other macro- 
economic variables. They indicated that monetary policy should avoid the extreme cases of maintaining rigid exchanged rates or allowing dramatic and severe depreciation of the koruna. Smídková, Barrell, and Holland (2003) employed the fundamental real exchange rate (FRER) method to examine the value of currencies and their relationships with other macroeconomic variables for the five EU accession economies including the Czech Republic before their accession. They reported that there were signs of currency overvaluations by the end of 2001 except for Slovenia and that currency stability or rigidity may not be consistent with economic growth. Hence, they suggested that some degree of exchange rate flexibility would be appropriate during the pre-EU era.

\section{The Model}

Extending Romer's (2000) IS-MP-IA model and assuming that the inflation rate is exogenous, we can express the goods market and monetary policy for the Czech Republic as

$$
\begin{gathered}
Y=C(Y-T)+I(R)+G+N X(\varepsilon, W Y) \\
R=R\left(\pi, Y, \varepsilon, R^{m}\right)
\end{gathered}
$$

where $Y=$ real output in the Czech Republic, $C=$ the consumption function, $T=$ government tax revenues, $I=$ the investment function, $R=$ the real interest rate, $G$ = government spending, $N X=$ net exports, $\varepsilon=$ the real exchange rate, $W Y=$ world output, $\pi=$ the inflation rate, and $R^{w}=$ the world interest rate.

Solving the above two simultaneous equations, I can write the equilibrium output in general form as

$$
\bar{Y}=f\left(\pi, G, T, \varepsilon, R^{W}, W Y\right)
$$

To reduce a high degree of multicollinearity among these variables, the government deficit spending variable, $D=G-T$, is used in empirical work:

$$
\bar{Y}=\mathrm{f}\left(\pi, D, \varepsilon, R^{W}, W Y\right)
$$

Let $C_{Y}>0, I_{R}<0, N X_{\varepsilon}>0, N X_{W Y}>0, R_{\pi}>0, R_{Y}>0, R_{\varepsilon}>0, R_{R^{w}}>0$. The endogenousvariable Jacobian is given by

$$
|J|=\left(1-C_{Y}\right)-I_{R} R_{Y}>0
$$

Let's suppose that the two functions in (1) have continuous derivatives. Based on comparative-static analysis, it can be shown that the impact of a change in $\pi, R^{w}$, or $\varepsilon$ on $\bar{Y}$ is

$$
\begin{gathered}
\frac{\partial \bar{Y}}{\partial(\pi)}=\frac{I_{R} R_{\pi}}{|J|}<0 \\
\frac{\partial P}{\partial\left(R^{V}\right)}=\frac{I_{R} R_{R^{W}}}{|J|}<0 \\
\frac{\partial \bar{Y}}{\partial(\varepsilon)}=\frac{N X_{\varepsilon}+I_{R} R}{|J|}>0 \text { if }\left|N X_{\varepsilon}\right|>\left|I_{R} R\right| \text { or } \\
<0 \text { if }\left|N X_{\varepsilon}\right|<\left|I_{R} R_{\varepsilon}\right|
\end{gathered}
$$


We expect that real output in the Czech Republic $(\bar{Y})$ has a positive relationship with government deficit spending and world output and a negative relationship with the inflation rate and the world interest rate, and a positive or negative relationship with the real exchange rate. An increase in government deficit spending, either due to an increase in government spending or a decrease in government tax revenues, would shift the IS curve to the right, raise the interest rate and real output. Increased world output or income would help the export sector and raise net exports and aggregate demand. The Czech National Bank would respond to a higher inflation rate by raising the interest rate, which in turn would reduce investment spending and shift the IS curve to the left. The CNB is likely to follow the trend of world interest rates in order to maintain the stability of capital flows and the exchange rate.

It is interesting to note that the impact of the depreciation of the koruna is unclear and depends upon whether the increase in net exports due to the depreciation would outweigh the negative impacts caused by the depreciation and rising interest rates. Bahmani-Oskooee and Miteza (2003) indicated that the impact of currency devaluations on the economy varies with the country under study, the specification of the theoretical model, and the research methodology used in empirical work.

\section{Empirical Results}

The sample ranges from 1994:Q1 to 2003:Q2. Earlier data for some of the variables are not available. All the data came from the March 2004 issue of the International Financial Statistics published by the International Financial Statistics. The inflation rate is derived from the consumer price index. The real exchange rate is equal to the koruna per USD times the price ratio between the U.S. and the Czech Republic. Hence, an increase is a depreciation, and vice versa. The U.S. treasury bill rate is used as a proxy for the world interest rate. World output is world industrial output with 1995 as the base year. Real output in the Czech Republic and real government deficit spending are measured in billions of the korunas.

The estimated regression based on the $\mathrm{GARCH}$ model is reported in Table 1. In the variance equation, the $\operatorname{GARCH}(1,1)$ process is appropriate as the coefficients for $\mathrm{ARCH}(1)$ and $\mathrm{GARCH}(1)$ are significant at the $1 \%$ level. It suggests that error variance is a function of past squared error and past error variance. All the coefficients are significant at the $2.5 \%$ level. As shown, real output has a negative relationship with the inflation rate, currency depreciation, and the world interest rate and a positive relationship with real government deficit spending and world output. Specifically, when the inflation rate rises by one percentage point, real GDP would decline by 3.87 billion korunas. When the government increases deficit spending by 1 billion, real output would rise by 0.39 billion. A depreciation of the koruna in real terms by one unit is expected to cause real output to decline by 1.81 billion. An increase in the U.S. Treasury bill rate by one percentage point would reduce real output by 2.58 billion. Therefore, the recent decrease in the interest rate in the U.S. is expected to help the economy in the Czech Republic mainly because the CNB responded by reducing its interest rate as well to stimulate private spending. As the world economy is gradually recovering, the export sector would benefit and help the Czech economy.

The GARCH model can be compared with the OLS regression reported in Table 2. As shown, the coefficients for the inflation rate, real government deficit spending, and the U.S. Treasury bill rate are insignificant at the $10 \%$ level and the coefficient for the real exchange rate is significant at the $10 \%$ level. If the OLS method is employed in empirical work without considering the GARCH model, we may draw a misleading conclusion that Romer's model may not apply to the Czech economy or that the inflation rate, real government deficit spending and the world interest rate would not affect the Czech output. 
Table 1

Estimated GARCH Regression (1994:Q1 - 2003:Q2)

\begin{tabular}{|c|c|c|c|c|}
\hline \multicolumn{5}{|c|}{$\begin{array}{l}\text { Dependent variable: } Y \\
\text { Method: ML - ARCH (Marquardt) } \\
\text { Sample(adjusted): } 1994: \mathrm{Q} 1-2003: \mathrm{Q} 2 \\
\text { Included observations: } 38 \text { after adjusting endpoints } \\
\text { Failure to improve likelihood after } 27 \text { iterations } \\
\text { Bollerslev-Wooldrige robust standard errors \& covariance } \\
\text { Variance backcast: ON }\end{array}$} \\
\hline & Coefficient & Std. error & $z$-statistic & Prob. \\
\hline $\begin{array}{c}C \\
\pi \\
D \\
\varepsilon \\
R^{w} \\
W Y\end{array}$ & $\begin{array}{r}215.184100 \\
-3.868148 \\
0.387424 \\
-1.812358 \\
-2.577659 \\
1.990369\end{array}$ & $\begin{array}{r}33.960300 \\
1.245537 \\
0.170121 \\
0.526083 \\
1.092386 \\
0.342227\end{array}$ & $\begin{array}{r}6.336341 \\
-3.105607 \\
2.277348 \\
-3.445006 \\
-2.359659 \\
5.815926\end{array}$ & $\begin{array}{l}0.00000 \\
0.00190 \\
0.02280 \\
0.00060 \\
0.01830 \\
0.00000\end{array}$ \\
\hline \multicolumn{5}{|c|}{ Variance equation } \\
\hline $\begin{array}{c}C \\
\text { ARCH(1) } \\
\text { GARCH(1) }\end{array}$ & $\begin{array}{r}96.228310 \\
-0.253885 \\
0.728245\end{array}$ & $\begin{array}{r}26.893000 \\
0.092014 \\
0.207785\end{array}$ & $\begin{array}{r}3.578192 \\
-2.759201 \\
3.504800\end{array}$ & $\begin{array}{l}0.00030 \\
0.00580 \\
0.00050\end{array}$ \\
\hline $\begin{array}{l}R \text {-squared } \\
\text { Adjusted } R \text {-squared } \\
\text { S.E. of regression } \\
\text { Sum squared resid } \\
\text { Log likelihood } \\
\text { Durbin-Watson stat. }\end{array}$ & $\begin{array}{r}0.611778 \\
0.504683 \\
15.955840 \\
7383.080000 \\
-151.053000 \\
1.482726\end{array}$ & \multicolumn{2}{|c|}{$\begin{array}{l}\text { Mean dependent var } \\
\text { S.D. dependent var } \\
\text { Akaike info criterion } \\
\text { Schwarz criterion } \\
\text { F-statistic } \\
\text { Prob( } F \text {-statistic) }\end{array}$} & $\begin{array}{r}360.485800 \\
22.671390 \\
8.423843 \\
8.811692 \\
5.712452 \\
0.000213\end{array}$ \\
\hline
\end{tabular}

Table 2

Estimated OLS Regression (1994:Q1 - 2003:Q2)

Dependent variable: $Y$

Method: Least squares

Sample(adjusted): 1994:Q1- 2003:Q2

Included observations: 38 after adjusting endpoints

White heteroskedasticity-consistent standard errors \& covariance

\begin{tabular}{|c|r|l|r|r|}
\hline Variable & Coefficient & Std. error & \multicolumn{1}{c|}{ t-statistic } & Prob. \\
\hline$C$ & 217.1842 & 49.89386 & 4.352924 & 0.0001 \\
$\pi$ & -3.369144 & 2.607986 & -1.291857 & 0.2057 \\
$D$ & 0.080571 & 0.266193 & 0.302678 & 0.7641 \\
$\varepsilon$ & -2.062765 & 1.211320 & -1.702907 & 0.0983 \\
$R^{w}$ & -2.719296 & 1.929658 & -1.409211 & 0.1684 \\
$W Y$ & 2.018702 & 0.423167 & 4.770456 & 0.0000 \\
\hline$R$-squared & 0.633091 & Mean dependent var & 360.4858 \\
Adjusted $R$-squared & 0.575762 & S.D. dependent var & \\
S.E. of regression & 14.76668 & Akaike info criterion & & 8.67139 \\
Sum squared resid & 6977.759 & Schwarz criterion & 8.625130 \\
Log likelihood & -152.9647 & F-statistic & 11.04303 \\
Durbin-Watson stat. & 1.427299 & Prob $(F$-statistic) & 0.000003 \\
\hline
\end{tabular}




\section{Conclusion}

In this study, real output in the Czech Republic has been examined by applying Romer's IS-MP-IA model and Engle's GARCH methodology. Major findings can be summarized as follows. A lower inflation rate, higher government deficit spending, a stronger koruna, a lower world interest rate, and a stronger world economy are expected to help Czech economy. In empirical work, the variance equation indicates that the $\operatorname{GARCH}(1,1)$ process is statistically significant and that error variance can be modeled by past squared error and past error variance. There are several policy implications. It appears that Romer's model may be considered in studying macroeconomic fluctuations because his model treats the interest rate as a monetary policy instrument and because his model avoids major criticisms of the conventional ISLM-AS model, namely, the mixture of the real and nominal interest rates and the use of the price level instead of the inflation rate. Although increased government deficit spending would help real GDP, there may be side-effects because more government borrowing may push up interest rates and crowd out private spending. Currency depreciation would help the export sector, but its overall impact on real output is negative if the government raises the interest rate to maintain the stability of the currency. Monetary policies made by major industrialized countries are expected to influence monetary policy of the Czech National Bank. Therefore, expansionary monetary policy pursued by the Federal Reserve Bank is expected to benefit the Czech economy as well.

There may be areas for future research. The inflation rate may be considered as an endogenous variable. Other world interest rates may be tried in empirical work. The IS model may be expanded to include several more variables if the data are available.

References

Bahmani-Oskooee, M., Miteza, L. (2003), "Are Devaluations Expansionary or Contractionary? A Survey Article." Economic Issues, 8(2), pp. 1-28.

Begg, D. (1998), "Pegging Out: Lessons from the Czech Exchange Rate Crisis." Journal of Comparative Economics, 26(4), pp. 669-690.

Brada, J. C., Kutan, A. M. (1999), "The Persistence of Moderate Inflation in the Czech Republic." Post-Soviet Geography and Economics, 40(2), pp. 121-134.

Dufek, P., Vávra, M. (2002), "Analysis of the Development of the Czech Economy in 2001 and Outlook for 2002 and 2003." Prague Economic Papers, 11(3), pp. 201-236.

Durčáková, J., Mandel, M. (2002), "Exchange Rate, Inflation, and Real Economic Growth in Transition Economies." Prague Economic Papers, 11(2), pp. 135-147.

Engle, R. F. (2001), "GARCH 101: The Use of ARCH/GARCH Models in Applied Econometrics." Journal of Economic Perspectives, 15(4), pp. 157-168.

Gali, J. (1992), "How Well Does the IS-LM Model Fit Postwar U.S. Data?" Quarterly Journal of Economics, 107(2), pp. 709-738.

Clarida, R., Gali, J., Gertler, M. (1998), "Monetary Policy Rules in Practice: Some International Evidence." European Economic Review, 42(6), pp. 1033-1067.

Halpern, L., Wyplosz, C. (1995), "Equilibrium Real Exchange Rates in Transition." London, CEPR Discussion Papers No. 1145.

Kutan, A. M., Brada, J. (1998), "The Persistence of Moderate Inflation in the Czech Republic and the Koruna Crisis of May 1997." Federal Reserve Bank of St. Louis, Working Papers 98-0121A.

Janáček, K., Zamrazilová, E. (2003), “Czech Economy in 2002: Record-Low Inflation.” Prague Economic Papers, 12(2), pp. 99-120.

Jonáš, J. (2000), "In Search for a New Anchor: Inflation Targeting in the Czech Republic." Prague Economic Papers, 9(3), pp.195-216. 
Jonáš, J., Mishkin, F. S. (2003), "Inflation Targeting in Transition Countries: Experience and Prospects." London, NBER Working Papers No. 9667.

Romer, D. (2000), "Keynesian Macroeconomics with the LM Curve." Journal of Economic Perspectives, 14(2), pp. 149-169.

Šmídková, K. (1999), "Estimating the Fundamental Equilibrium Exchange Rate for the Czech Republic." Prague Economic Papers, 8(1), pp. 53-67.

Šmídková, K., Barrell, R., Holland, D. (2003), "Estimates of Fundamental Real Exchange Rates for the Five EU Pre-Accession Countries." Prague Economic Papers, 12(4), pp.291-315.

Taylor, J. B. (1993), "Discretion versus Policy Rules in Practice." Carnegie-Rochester Conference Series on Public Policy, 39(0), pp. 195-214.

Taylor, J. B. (1998), "Applying Academic Research on Monetary Policy Rules: An Exercise on Transitive Economics." Manchester School, 66(0), Supplement, pp. 1-16(a). (1998), "Monetary Policy and the Long Boom." Federal Reserve Bank of St. Louis Review, 80(6), pp. 3-11(b).

(1999), Monetary Policy Rules. Chicago and London: University of Chicago Press. 